Grand Valley State University

ScholarWorks@GVSU

Papers from the International Association for

Cross-Cultural Psychology Conferences

IACCP

2014

\title{
The Role of Spiritual Faith Healers in Reducing or Reinforcing the HIV Stigma: A Qualitative Study
}

Nkeke Lesolang

University of Limpopo, nkeke.lesolang@ul.ac.za

Follow this and additional works at: https://scholarworks.gvsu.edu/iaccp_papers

Part of the Psychology Commons

\section{ScholarWorks Citation}

Lesolang, N. (2014). The role of spiritual faith healers in reducing or reinforcing the HIV stigma: A qualitative study. In L. T. B. Jackson, D. Meiring, F. J. R. Van de Vijver, E. S. Idemoudia, \& W. K. Gabrenya Jr. (Eds.), Toward sustainable development through nurturing diversity: Proceedings from the 21st International Congress of the International Association for Cross-Cultural Psychology.

https://scholarworks.gvsu.edu/iaccp_papers/117/

This Article is brought to you for free and open access by the IACCP at ScholarWorks@GVSU. It has been accepted for inclusion in Papers from the International Association for Cross-Cultural Psychology Conferences by an authorized administrator of ScholarWorks@GVSU. For more information, please contact scholarworks@gvsu.edu. 


\title{
The Role of Spiritual Faith Healers in Reducing or Reinforcing the HIV Stigma: A Qualitative Study
}

\author{
Nkeke Lesolang \\ (nkeke.lesolang@ul.ac.za) \\ University of Limpopo, South Africa
}

\begin{abstract}
The role of spiritual faith healers in managing various conditions of ill-health has been studied and debated. The aim of this study was to explore spiritual faith healers' understanding and conceptualisation of HIV/AIDS stigma and the role they play in reducing or reinforcing HIV/AIDS stigma in their communities. A qualitative approach, and in particular, the grounded theory methodology was used. The application of this methodology included personal interviews with eight practising spiritual faith healers in Limpopo Province (South Africa), while additional information was gleaned from the literature review. The researcher focused on the participants' conceptualisation of HIV stigma, from the context of the African world view in order to gain insight into the roles of these spiritual faith healers. The findings indicated that spiritual faith healers tended to show a less positive attitude towards people living with Aids. However, the findings suggest that spiritual faith healers perceive themselves to be having a definite role to play in reducing HIV/ AIDS stigma in their communities. These findings are discussed in the context of South African national policies relating to HIV and AIDS. The study is concluded by suggesting that HIV testing must be compulsory for every person who consults in a hospital. Such a policy move could contribute positively in terms of health promotion.
\end{abstract}

\section{Introduction}

Numerous research studies are currently focussing on HIV/AIDS stigma in Africa because of its severity and the fact that it seems to be highly stigmatized in the Sub-Saharan region. The "lack of scientific research on the manifestation of HIV/AIDS stigma (in Sub-Saharan Africa) presents a serious challenge to the understanding, alleviation and prevention of HIV/AIDS related stigma" (Kelly, 2002).

In a study focusing on HIV stigma in the African context, Kelly referred to the vulnerability to HIV-stigma and discrimination as linked to existing stereotypes, including poverty, intolerance and inequality between women and men. Kelly's study shows that in Sub-Saharan Africa, issues of gender as well as poverty, lack of economic opportunities, limited access to education, information as well as traditional norms and practices, significantly increase a woman's vulnerability to HIV and lie at the root of her experience in trying to cope with the related stigma and discrimination.

A number of studies have been conducted mostly from HIV/AIDS infected and affected persons in South Africa including Limpopo, (France (2005); Fredericksson \& Kabanus (2005); Haber, Roby \& High-George (2011); Kelly (2002); Link \& Phelan (2001): Natrass (2004) and Nyblade, MacQuarrie, Phillip, Kwesigabo, Mbawambo, Ndega, Katende, Yuan, Brown \& Staple (2005). Whilst these studies have suggested that existing stereotypes, including poverty, lack of economic opportunities, limited access to education, information as well as traditional norms and practices, significantly increase a woman's vulnerability to HIV and lie at the root of her experience in trying to cope with the related stigma and discrimination, none of them has investigated the issues related to HIV and AIDS from the perspective of the spiritual healers. This study therefore, addresses this gap by focusing on spiritual healer's understanding of HIV stigma and the role that they see themselves playing to reduce or reinforce the stigma.

\section{Stigma in the Context of Religious Communities}

According to Lagarde, Nel, Seck Gueye-Ndiye, Piau, Pison, Delaunay, Ndoye, and Mboup, (2000) it has been recognised that religion plays an important role in relation to the HIV/AIDS epidemic. Religious elements 
include doctrinal positions and religious teachings with which ministers address HIV/AIDS and HIV prevention and efforts undertaken by the church in communities and societies within which they work. Furthermore, the church has direct "jurisdiction" over issues of personal behaviour, morality, family life, and belief. Their regular involvement with members and followers includes direct contact with people at key life events such as birth, coming of age, marriage, and death. Their position includes being a spiritual home for members and as a source of strength, support and hope for people who are ill or in need.

Manglos and Trinitapol (2011) argue that faith healing can be understood as the third therapeutic system that co-existed with the well-documented biomedical and traditional systems. Its success in the healing approaches lies with their unique ability to combine individual pragmatic and communal-ritualized aspects of healing to inform interpretations of AIDS epidemic and its consequences (p.107). Therefore, a great potential exists within the religious sector to provide care, comfort and unique spiritual support to HIV/AIDS infected and affected communities. According to France (2005) and Trinitapoli (2006) the church has not yet comprehensively addressed the ambivalent but often negative interpretation of sexuality that is common in religious dogma. This ambivalence has been transformed into widespread fear of people with HIV and cruelty towards them. Furthermore, because religious teachings generally encourage love one's neighbour, acceptance of others, and encourages tolerance towards "others" which may be different from one's religion, race and creed, Christians should not be prejudiced to those less fortunate than themselves (France, 2005:9).

Nicholas and Durrheim (1995) refer to religiosity as being conceptualized as personal control against deviance and, therefore, positively associated with conventionality and conformity. A study by Lagarde et al., (2000) on Christian and Muslim leaders in Senegal has revealed a minimum involvement in AIDS prevention, suggesting that religion is negatively linked to preventative behaviours. Some studies suggested that religion has the ability to modulate preventative behaviours, and suggest that there is a need to intensify the efforts to involve religious leaders at the local level (Agadjanian (2005); Chiakwa, (1999); Ejizu, (2007); Lagarde, et al, (2000); Leeuw, (2004); Mbiti, (2006) and Sandlana, (2005). AIDS-stigma is also a key obstacle to HIV prevention and AIDS care, and to date very little research has been done to investigate the impact of people's attitude toward the infected and affected. Parker and Birdsall (2005) argues that observers are largely in agreement that early on in the epidemic, faith based organizations constituted "part of the problem" rather than "part of a solution". The faith based organizations have been faulted for their delayed responses, for failure to acknowledge the scope of the implications of rising HIV infection rates and for moralistic, judgemental and socially conservative stances towards HIV/AIDS which has contributed to silence and secrecy. The association of HIV infection with poor moral behaviour, and the failure to openly discuss the root causes underpinning HIV transmission, particularly differentials in power, have contributed to the stigmatization and discrimination of people living with HIV/AIDS within the church.

While there is great potential within the religious sector to provide love and support among its members, there is also evidence of reluctance from individuals within this sector to positively respond to national calls for prevention and educating the communities about HIV/AIDS because of their moral judgement stand 'sex before marriage is a sin'.

\section{African Religion in IIIness and Health}

In a study focussing on HIV stigma in the African context, Kelly (2002) referred to vulnerability to HIV stigma and discrimination as linked to existing stereotypes, including poverty, intolerance and inequality between women and men. Kelly's study shows that in Sub-Saharan Africa, issues of gender as well as poverty, lack of economic opportunities, limited access to education, information as well as traditional norms and practices significantly increase a woman's vulnerability to HIV lie at the root of her experience in trying to cope with the related stigma and discrimination.

Traditional African religion plays an important part in shaping African cultures. It is through this religion that the community is able to live in harmony with one another. According to Mbiti (2006), from birth to death of an individual, the family and community conduct certain rituals for every occasion and every individual 
understands the ritual for the occasion. The whole community is expected to practise the culture and, therefore, the belief is that illness occurs if one of the family or community does not adhere to cultural beliefs. Disagreeing with these beliefs is regarded as culturally immoral and evil because Africans regard moral values as a high priority (Mbiti, 2006). Anything which does not adhere to these values is regarded as a taboo and is punishable by the ancestors either by becoming ill or a misfortune befalling the person. Africans, therefore, emphasise illness or the social construction of sickness rather than the disease or the biomedical sickness (Katz \& Wexler, 1989; Mbiti, 2006). Chiakwa (1999) puts it in context by declaring that sickness is evidence of a breakdown of physical, social as well as spiritual mechanisms of the individual and the community. He argues that man was believed to be a unitary being, consisting of biological body and the spiritual body. He had to be healed medically, socially, psychologically and spiritually. The healing, therefore, becomes a transition towards greater meaning, balance, connectedness, and wholeness, both within the individual and between individuals and their environment (Katz \& Wexler, 1989; Muthali, 2006). Benor (2006) adds that it lets one feel one is part of a larger "whole", a cosmic, transpersonal awareness. It is the latter which gives healing the label "spiritual" healing.

According to Lagarde, et al., (2000), religion plays an important role in relation to the HIV/AIDS epidemic. Furthermore, the church has "jurisdiction" over issues of personal behaviour, morality, family life and belief. Their regular involvement with members includes direct contact with people at key life events such as birth, coming of age, marriage and death. Their position includes being a spiritual home for members and a source of strength, support and hope for people who are ill or in need (Lagarde et al., 2000).

\section{Aim of the Study}

The aim of the study was to explore spiritual faith healers' understanding and conceptualisation of HIV/ AIDS stigma and the role they play in reducing and reinforcing stigma in their communities. Specifically, the study sought to answer the following research questions:

- How do spiritual faith healers understand and define HIV/AIDS stigma?

- What are spiritual faith healers' specific roles in reducing or reinforcing HIV/AIDS stigma?

\section{Methodology}

This is a qualitative study that used the grounded method approach as a mode of enquiry. Strauss \& Corbin, (1987) describes grounded theory as a research method in which theory is developed from data, rather than the other way round. This method was chosen for this research particularly because it helped the researcher to look for a pattern within the African traditional and spiritual faith healing contexts, and develop ideas about patterns or/and relationships from pre-existing theories or inductions. She then focused on a few regularities and made contrasts with alternative explanations.

A total of eight participants were carefully chosen on the basis of all of them practicing spiritual faith healing in their communities. The participants were selected through snowball sampling. Snowball is a method for identifying and "sampling" or selecting the cases in a network. It is a multi-stage technique, which begins with one or a few people or cases and spreads out on the basis of links to the initial cases. According to Neuman (2006) this practical way of gaining access to respondents has theoretical as well as methodological advent ages. Participants interviewed were from the traditional African churches as well as Christian denominations. Four males and four females were interviewed for the study. Their ages ranged from forty five to sixty nine years. Six had secondary education while three had a post- secondary level of education.

The study was conducted in the five (5) districts of Limpopo, namely, Capricorn, Waterberg, Vhembe, Sekhukhune, and Mopani. These areas represent the origin of different ethnic groupings in the Province, namely, Northern Sotho, Xitsonga, and Tshivenda. Twenty-one point six per cent (21.6\%) of the people living in these areas are unemployed and are communal, while fifty-five point seven per cent $(55.7 \%)$ are not economically active (Statistics South Africa, 2005). They depend on subsistence agriculture while many of them are poor. Due to their communal living, most of these people believe in African churches which combine roles both Christian as well as African healing methods such as African rituals. 


\section{Data Collection and Analysis}

In depth semi-structured interviews were conducted in Sepedi, Xitsonga, and Tshivenda the three languages commonly spoken in Limpopo Province. This gave the interviewer the chance to formulate more questions based on specific themes or issues that were formulated beforehand.

All interviews were tape-recorded and fully transcribed and analysed qualitatively. The researcher interviewed the participants individually at the spiritual healers' gatherings. The medium of communication was the participants' choice, usually the home language. Thereafter, the translations were double- checked by two bilingual researchers by means of back translation. Semi-structured interviews were used as a method of data collection while the data were analysed qualitatively. The author then analysed the interviews transcripts independently using NVivo by QRS International, qualitative analysis software, and applying a grounded theory approach by which empirical data are thematically categorized by induction. The second analysis revealed that the themes from the first and second analyses, although differently grouped, extracted the same issues from the empirical material. This was taken as a confirmation of the grounding of the analysis in the data. To be included as a theme, supporting data had to be contained in the in-depth interviews from all participants. The open-ended questions were analysed manually.

\section{Results}

The following two themes were extracted from the interviews with spiritual healers, namely: Spiritual faith healers' understanding of HIV/AIDS stigma; and the roles of spiritual faith healers in reducing or reinforcing HIV stigma.

\section{Theme 1: Spiritual faith healers' understanding of HIV/AIDS stigma}

It does appear that spiritual healers have an understanding of what is considered the indications or symptoms of HIV and AIDS as reflected in the following theme:

Sub-theme 1: Understanding of HIV issues. This is what the participants said:

Participant 1: "People will separate themselves from such a person, his/her family and friends. It hurts. They will talk about the person behind his/her back and also avoid him/her. Such a person will be naturally discriminated for the discriminated for disease or condition unacceptable by society. Such a person is cut off from the rest of society because of disclosure".

Participant 2: "People are not opening up, so you might not know if a person is negative or positive. People do not want to disclose their status".

Spiritual healers tended to acknowledge that HIV is spread in many ways as reflected in the following extracts:

Participant 1: "I had denial that it cannot happen to me, until 2007 when I developed a full perspective of what HIV/AIDS is, because I saw these people and developed a feeling of fear and now I had to restructure my behaviour to that of acceptance and this thing is real".

Participant: 2: "It was scary; people tell you that if you have this virus you are going to die. Now I do believe because it is here and just have to find ways of preventing it".

Participant 4: "It pains me to see how the whole thing of HIV is, because when the person coughs he/she coughs blood, so it is painful to see that".

Participant 5: "It is terrible because by that time I was given some pictures of HIV infected people. It was horrible to see that I felt like everyone can be a victim. The discrimination is very high against those infected by the virus. What is needed from us is support to these people who are HIV positive".

Participant 6: "I felt there was denial, people are not afraid to hide it. These people need sympathy".

Participant 8: "The unfortunate part was that HIV was presented by politicians as being dangerous, a killer disease. People with HIV were promiscuous, irresponsible, truck-people, prostitutes. It was actually scary in a way it was said. It made me feel scary. Obviously, the kind of feelings one has that makes one scary".

All the spiritual healers expressed the fact that many people in the society do not go for testing. Some members of the community give reasons such as being afraid of being infected through association with people 
who have HIV and are rejected by society because of being labelled after disclosure. Spiritual healers commented: "This displays society's insensitivity and ignorance" (Participant 8).

Some of the spiritual faith healers praised organizations in the society which created HIV awareness programmes. These organizations encourage testing and also sharing of experiences of people which help in accepting and understanding HIV better "there are a lot of organisations spreading the word that HIV/AIDS kill and it is very much alive. There are many interactions about HIV/AIDS, but people do not care about what happens as long as they enjoy life" (Participant 2). "...being HIV, people should learn to trust one another, because we don't trust each other" (Participant 3).

It was also regarded as a way of eliminating the stigma of ignorance and discrimination. There was also a concern by spiritual healers that the high pregnancy rate means faster spreading of HIV/AIDS. Spiritual healers alluded to the secrecy clause which is enshrined by the Government in the HIV and AIDS Act which states that, "it is a person's right to disclose or not to disclose". They further commented: "It becomes difficult to help, and a real challenge to society because people do not talk about HIV and nobody knows who is positive or negative. Only if people open up, will society be able to help them"(Participant 8).

A number of spiritual faith healers raised concerns about stigma and discrimination meted by members of the society against PLWA. The following extracts by two spiritual healers illustrate this point: “..... as having no self -control, regarded as irresponsible, being a slut as misbehaved" (Participant 2). "If you deal with the person, you should wear gloves, wash your hands, and that the remaining food eaten by the affected must be thrown in the toilet. HIV is meant for others and not those next to you" (Participant 3).

Based on the above findings, it could be suggested that spiritual faith healers understand HIV/AIDS stigma.

\section{Theme 2: Roles of spiritual faith healers within the church:}

From this theme three subthemes emerged. Church involvement, the church is not doing enough and denial by church members.

Sub-theme 2.1: Church involvement: The church's involvement in contributing to the AIDS pandemic has been acknowledged world-wide. The contribution is that the church first accepts or/and welcomes their condition which is symbolical in that the HIV person attends church like any other person with no special attention to her/his condition. By reading the scriptures, the church supports the infected person morally and spiritually and also prays for them. For example, the church accommodates an infected person like any other person. It gives support through the scriptures which are read to encourage and motivate the infected. Furthermore, it supports them physically by giving food parcels to the sick, telling them it is not the end of the world and organising workshops for caregivers, and also spiritually by giving them biblical texts to strengthen them, paying them visits and praying for them. The spiritual faith healers commented: "the church tries to do practical things but reality on the ground is difficult and different" (Participant 8). All the spiritual healers stated that "HIV stigma is not normal stigma" (Participant 1). Their perception is that the HIV stigma is inflammatory to the whole world, meaning if you are stigmatized by others, you are 'gone/nothing'. The church helps these people to live positively, assuring them God's and the church's love.

Sub-theme 2.2: Church is not doing enough: Although AIDS has established itself in Africa, most of the spiritual faith healers mentioned that "pastors do not talk about the cure for the virus, church does not dwell much on the HIV issues, these issues are not discussed in church" (Participants 5, 6). As much as the church tries to build centres to encourage church members, the connotation is that those who go for such sessions are already infected by HIV. It separates people from the congregation and therefore, they become stigmatized. The church was also noted as not doing enough for those with HIV/AIDS. Most of the pastors are old and they regard talking about sex as promoting it in the church. The church does not even talk about a cure for the virus and there is still a lot of negligence in the church in that as grown up persons and pastors, they still view HIV as a punishment from God. "... referring to the church, there is still a lot of negligence, there is no talking about the cure for the virus. They don't take care of equipment's they use. For example, equipment is used for several people without sterilization. What I can say is that the church is neglecting these HIV/AIDS issues" (Participant 
1). Another spiritual healer mentioned that ... "generally the issue is not talked about in church. Up to now, most churches do not dwell much into the whole HIV issue" (Participant 5). Other churches regard HIV issues as socio-cultural. For example, they regard a person as being bewitched or having neglected cultural taboos and would therefore, use rituals as a cure. Some churches believe that "Satan is using us, and people don't take note that Scriptures testifies it" (Participant 5).

Sub-theme 2.3: Feelings of denial by church members: The spiritual faith healers showed an understanding of HIV issues, by stating that "sometimes it is not the person's fault that they found themselves being positive, and that they see the treatment for HIV as the same as any other treatment" (Participant 4). Another spiritual faith healer mentioned that "the more people talk about HIV, people tend to accept and change their mind set about the disease" (Participants 2, 4, 6). Spiritual healers as part of the community are also involved in cultural activities such as spiritual rituals. These then make them understand their flock informally outside the church as well as formally within the church activities.

\section{Discussion}

The results of the study identified two themes namely: spiritual faith healers' understanding of HIV stigma and roles of spiritual faith healers within the church. The results of this study reveal that spiritual healers as part of the community understand the HIV issues in the societies they live in and are also involved in cultural activities such as spiritual rituals. This makes them understand their flock informally, outside the church as well as formally in church activities. However, spiritual faith healers are also bound by the church dogma which expects them to practice what the church prescribes. The church has a stand on HIV issues. It helps PLWA to live positively assuring them God's love and supporting them morally and spiritually. It accepts their condition such as "love your neighbour as you love yourself". This is what the Bible prescribes. However, most of the pastors are old, and regard talking about sex as promoting it in the church and therefore, view HIV as a punishment from God.

According to Ejizu, morality in Africa is s imperative of the human make-up and not an option and, therefore, society might invoke severe punishment on anyone who would try to oppose or disobey a promulgated law or norm of morality. For most African groups, ostracizing an individual or family that has disobeyed the community is thought to be the most severe punishment that could be meted out to anybody. This would usually put the family in a predicament for fear of the tremendous power of the community in a traditional African background. Stigma is therefore, regarded as all that which is not in line with the traditional African view, for example, most spiritual faith healers commented that "The infected are views by society as promiscuous, irresponsible, truck people, and prostitutes". This labelling is followed by alienation by society and therefore, are discriminated against.

The society insists on culture and the adherence thereof by its people. It also stigmatizes people quietly and without notice, the society shuns those who may not toe the line. Furthermore, stigma and discrimination hinder preventative efforts and make positive people fear to seek help/care and support from family and friends rather they go to church and also find it discriminating in a sense. Society also pushes the infected and their families away by blaming them for deviating from the African moral standards, thereby stigmatizing them by not trying to understand their fate. Some authors contend that society's mind-set lies in the African culture which must be accommodative towards those who are infected and affected. If HIV testing is compulsory, society will regard HIV as any other illness and therefore stigma will automatically be reduced among societies.

Furthermore, society must adapt to the demands of how to behave towards others, and start supporting them because they need love, caring, empathy and encouragement. These actions are what Herek (2002) calls "intrinsic" religious orientation. In other words, since the intrinsic use religious teachings to inform their everyday interactions with others, they should love their neighbour, for them that is the right thing to do.

A statement such as If you deal with the person you should wear gloves, wash your hand, and that the remaining food eaten by the affected must be thrown in the toilet, refers to what Nyblade et al. (2005) call "enactment of stigma" through discriminatory practices, including physical isolation. These include, for example, 
fear of contagion in separating eating utensils and living quarters, social isolation from events, loss of social networks, and diminished standing in the community also verbal discrimination and abuse, gossip and blaming.

The spiritual faith healers identified families dissociating themselves from the patients for fear of being infected, and fear of the unknown caused by promiscuous relationships of one of the family members. This is in line with what Herek (2002) defines as symbolic context of stigma based on pre-existing attitudes towards a person or group targeted by HIV. This might be economic, political or within the local community context. He also defines what he calls "felt stigma" which motivates individuals with stigmatized condition to attempt to "pass" as members of the non-stigmatized majority. Some of the participants mentioned the question of non-disclosure by HIV infected persons. This Herek argues, reduces their likelihood of being targeted as having HIV. But it also disrupts their lives because of non-disclosure. Spiritual faith healers alluded to the government "HIV secrecy clause" which is a challenge to society due to non-disclosure as a right.

According to Herek, stigma and discrimination hinder preventative efforts and make positive people fear to seek help/care and support and thus adopt what he calls "successive passing". That is, people pretend and act as if things are normal so that they are not identified as the "other". Because of the blame by society, PLWA attend church regularly but do not trust anyone including the church elders.

Lunginaah, Yiridoe, and Taabazuing (2005) noted that dimensions of culture in Africa, such as values, beliefs and norms are culture constructs which influence marital and other social behaviours (Mbiti, 2006). In their studies, Lunginaah et al., (2005) acknowledges the potential role the churches could play in HIV/ AIDS prevention efforts to eradicate the AIDS epidemic which cannot be done without the help of the African churches. One agrees in that the African churches involve people's settings in their healing processes, that is, the body, family and environment of the patient. 'Abdu'l-Baha (2007) contends that as the world crumbles in one's life, spirituality consoles the person. In such a situation a person looks to God for survival.

Sub-theme 2.2 Church is not doing enough. Although AIDS has established itself in Africa, Agadjanian (2005) argues that informal communication regarding HIV/AIDS is still characterized by considerable uncertainty, ambivalence and stigmatization. However, the church is not doing enough in its contribution towards alleviating the plight of the infected. One argues that it separates people from the congregation and, therefore, they become stigmatized. Allport (1954) explains the setting of people apart from other individuals or groups through attachments of a perception of negative values as prejudice. For, example, as much as the church tries to build centres to encourage church members (the infected and affected), connotation is that those who go for such sessions are already infected by HIV.

Parker and Birdsall (2005) noted the inconsistent and sometimes contradictory roles by the church, which need to be understood as dependent on many contextual factors both in the micro as well as the macro level. These may be attitudinal or unofficial stances by religious bodies on the question of HIV/AIDS. They include societal factors, which involve the position occupied by a faith group or religion within a community or society as a whole. The researcher's understanding is that there are no continuous workshops for the pastors regarding the HIV pandemic and the church is actually avoiding HIV issues are not discussed in church.

\section{Summary}

Spiritual faith healers showed an understanding of HIV stigma. Their stance was that of being helpless reinforces stigma because of the church dogma which avoids HIV issues. The church avoids the realities of the world but concentrates at how many people attend church as compared to the other churches. Therefore, sticking to what the Bible is advocating is more comfortable and safer for the church than deviating for a fight against AIDS. The programmes offered by the church are discriminatory. For example, person feels singled out of the group (congregation) to attend such programmes. A pastor sees HIV as punishment from God, but this is within the church rules. The "HIV secrecy clause" enshrined in the South African National Policy on HIV/ AIDS for learners and Educators (August 1999) have a potential to prevent those affected. It is suggested that the tendency not to disclose has the potential to encourage stigmatization and discrimination whilst at the same time hindering efforts to find solutions to the problem. 


\section{Limitations of the Study}

The limitation was that spiritual faith healers were more comfortable to be interviewed at their council offices as a group than as individuals. This compromised the study because each had to say what was perceived as right and not what he/she thought was right. Another limitation was that PLWA were not interviewed in this study. Their own understanding of HIV/AIDS stigma might have shed more light that could have enriched the researcher's interpretation of the results. Lastly, the results of the present investigation cannot be generalized to the entire population of the spiritual faith healers in Limpopo Province since only a small fraction was interviewed for the study.

I want to acknowledge The Medical Research Council (MRC, South Africa) for providing financial assistance towards the cost of this research. Opinions expressed in this work, or conclusions arrived at, are those of the author and are not to be attributed to the Medical Research Council.

\section{Recommendations}

The church must give continuous training/workshops to its pastors on HIV issues. Second, more teachings on HIV in church will influence the church community to regard it as any other disease. Third, testing should be compulsory for every person who consults in a hospital. This could encourage HIV/AIDS to be accepted as the only condition of ill health not a killer disease. Lastly, future studies on this topic can be successful if the field worker is one of their own. Meaning somebody they know.

\section{References}

Abdu'l-Baha (2007). Faith healing. Retrieved from http://www.geocities.com/quddus/Christian/1faithhealing.html. Adjanian, V. (2005). Gender, religious involvement, and HIV/AIDS prevention in Mozambique. Social Science \& Medicine, 61, 1529-3539.

Allport, G. W. (1954). The Nature of prejudice. Abridged. DAB. Cambridge, MA: Harvard University Press.

Benor, D. J. (2006). Spiritual healing and psychotherapy. Retrieved from http://www.athealth.com/Consumer/farticles/ Benor.html.

Chiakwa, V. N. (1999). African traditional healing vis-a-vis Western healing. In S. N. Madu, P. K. Baguma \& A. Pritz (Eds.), Cross-cultural dialogue on psychotherapy in Africa (pp. 193-208). Pietersburg, South Africa: World Council for Psychotherapy African Chapter.

Creswell, J. (1994). Qualitative Inquiry and Research Design. London, United Kingdom: Sage Publications.

Christian Century. (2000). AIDS and the church in Africa. Christian Church, 22, 2-9.

Ejizu, C. I. (2007). African traditional religions and the promotion of community- Living in Africa.

Feeney J. (2005). Believe God for spiritual healing. A bible study on divine healing. Retrieved from http://www.jimfeeney. org/divinehealing.html.

Foster, G. (2009). Part of a solution: Faith-based responses to HIV and AIDS in Africa. In R. G. France, N. (2005). Stigma and HIV/AIDS in Africa. Retrieved from http://www.hdnet.org/stigma/Background\%20Information/ Review520of\%20issues\%20and20responses.htm.

Frederiksson, J., \& Kanabus, A. (Eds.) (2005). HIV/AIDS: Stigma and discrimination. Retrieved from http://www.avert. org/Saidsstigma.htm.

Haber, D. B., Roby, J. L., \& High-George, L. D. (2011). Stigma by association: the effects of caring for HIV/AIDS patients in South Africa. Health and Social Care in the Community, 19, 541-549.

Herek, M. H. (2002). Thinking about AIDS and stigma: A psychologist's perspective. Journal of Law, Medicine \& Ethics, 30, 594-607.

Katz, R., \& Wexler, A. (1989). Healing and transformation: Lessons from indigenous people (Botswana). In K. Pelzer \& P. O. Ebigbo (Eds.), Clinical psychology in Africa (South of the Sahara, the Caribbean and Afro-Latin America) (pp. 19-37). Uwani, Nigeria: Chukwa Printing.

Kelly, M. M. (2002). Fighting AIDS-related stigma in Africa. Retrieved from http://www.prb.org/Template.cfm?

Lagarde, E., Enel, C., Seck, K., Gueye-Ndiaye, A., Piau, J., Pison, G., Delaunay, V., Ndoye, I., \& Mboup, S. (2000). Religion and protective behaviours towards AIDS in rural Senegal. AIDS 2000, 14, (13), 2027-2033. 
Leeuw, M. J. (2004). Indigenous knowledge systems: 'religion' idem 'philosophy'. In M. Masoga, \& A. Musyoki (Eds,), Building on the indigenous - An African perspective (pp. 20-36). Paper presented at the International Conference on Indigenous Knowledge Systems, University of Venda for Science and Technology, Thohoyandou, South Africa, 12-15 September (pp.20-36). University of Venda Science \& Technology, South Africa: National Research Foundation.

Link, B. \& Phelan, J. (2001). Conceptualising stigma. Annual Review of Sociology, 27, 363-385.

Lunginaah, I. N., Yiridoe, E. K., \& Taabazuing, M. (2005). From mandatory to voluntary testing: Balancing human rights, religious and cultural values, and HIV/AIDS prevention in Ghana. Social Science \& Medicines, 61, 1689-1700.

Manglos, N. D., \& Trinitapoli, J. (2011). The third therapeutic system: Faith healing strategies in the context of a generalized AIDS epidemic. Journal of Health and Social Behaviour, 52, 107-122.

Mbiti, J. S. (2006). Introduction to African religion. Nairobi, Kenia: Sunlitho.

Muthali, A. C. (2006). Health problems that require no "Medication": The case of ancestor-related illness among the Tumbuka Northern Malawi. Nordic Journal of African Studies, 15, 367-379.

Natrass, N. (2004). The moral economy of AIDS in South Africa. Cambridge, United Kingdom: Cambridge University Press.

Neuman, W. N. (2006). Social research methods. Qualitative and quantitative approaches. London, United Kingdom: Allyn and Bacon.

Nicholas, L., \& Durrheim, K. (1995). Religiosity, Aids and sexuality knowledge, attitudes, beliefs, and practices of Black South African first-year university students. Psychological Reports, 77, 1328-1330.

Nyblade, L., MacQuarrie, K., Phillip, F., Kwesigabo, G., Mbawambo, J., Ndega, J., et al. (2005). Working report measuring HIV stigma: Results of a field test in Tanzania. Synergy Action Project.

Parker, W., \& Birdsall, K. (2005). HIV/AIDS, stigma and faith-based organizations: a review. Centre for AIDS development, research and evaluation (CADRE) on behalf of Futures Group. Johannesburg, South Africa: CADRE.

Sandlana, N. S. (2005). The role of African traditional and religious healing practices in the provision of psychological well-being. In N. S. Madu \& S. Govender (Eds.), Mental health and psychotherapy in Africa (pp. 466-479). Pietersburg, South Africa: World Council for Psychotherapy African Chapter.

Statistics South Africa. (2005). Mortality and causes of death in South Africa, 1997-2003. Findings from death notification report. Pretoria, South Africa: Statistics South Africa.

Strauss, A., \& Corbin, J. (1998). Basics of qualitative research: techniques and procedures for developing grounded theory. Thousand Oaks, CA: Sage Publications.

Trinitapoli, J. (2006). Religious responses to AIDS in Sub-Saharan Africa: An examination of religious congregations in rural Malawi. Review of Religious Research, 47, 253-270.

Willms, D. G., Arratia, M. \& Makondesa, P. (2004). Malawi faith communities responding to HIV/AIDS: Preliminary findings of a knowledge translation and Participatory-Action Research (PAR) project. African Journal of AIDS Research, 3, 23-32. 